\title{
Analysis of Innovation of Party Building in Non Public-owned Economic Organizations in the New Situation
}

\author{
Yongjiu Shu ${ }^{1}$ \\ ${ }^{1}$ Political College, Sichuan Agriculture University, Ya'an, China \\ Correspondence: Yongjiu Shu, Political College, Sichuan Agriculture University, Ya'an 625014, Sichuan, China. \\ E-mail: shuyongjiu@126.com
}

Received: July 28, 2012 Accepted: August 16, 2012 Online Published: November 30, 2012

doi:10.5539/ass.v8n15p261 URL: http://dx.doi.org/10.5539/ass.v8n15p261

This paper is the research result of philosophical and social science planning project in the Sichuan Province (SC10W209), and the research result of rural development and research center project in Sichuan Province (CR1126).

\begin{abstract}
Since the opening-up and reform in china, the economy of non public-owned economic has become an important part in the development of social economy. Based on innovation is the source of social development and power as the center thought, with regards to the problems which party building of non public-owned economic organizations are faced with currently, such as, difficulty in unifying recognition, difficulty in organizational construction, difficulty in organizational management, difficulty in team construction and difficulty in playing its functions, etc, this paper around the main body of the party content, analyses the basic thought and measures of party building in non public-owned economic organizations in the aspects of innovation of concept, innovation of theory, institutional innovation, innovation of carrier and innovation of management, etc. It is an important subject to consolidate the base of the ruling status of $\mathrm{CPC}$, and promote the healthy development of non public-owned economic organizations.
\end{abstract}

Keywords: new situation, non public-owned economic organization, party building, innovation of party building

\section{Introduction}

Since the opening-up and reform in china, the economy of non public-owned economic organizations has been developed fast, and has become an important growth pole in the development of social economy. However, the party building of non public-owned economic organizations obviously falls behind requirement of development of the situation. It is currently faced up with a series of problems, such as, difficulty in unifying recognition, difficulty in organizational construction, difficulty in organizational management, difficulty in team construction and difficulty in playing its functions, etc. How to innovate party building in non public-owned economic organizations, consolidate the base of the ruling status of CPC, and promote the healthy development of non public-owned economic organizations is an important subject of party building in the new period which is urgent to study and resolve.

\section{Challenges Faced up by Party Building of Non Public-owned Economic Organizations in a New Situation}

\subsection{Building of Party Organizations Obviously Falls behind Development of Non Public-owned Economic Organizations}

Ever since the reform and opening up in China, the development speed of privately owned economy in China has been exponentially faster than the growth speed of the national economy and the ratio of privately owned economy to GDP has exceeded $1 / 3$. At present, privately owned industry has accounted for $40 \%$ or so of the growth value and sales revenue of the national industry and accounted for more than $60 \%$ of the total sales amount and total volume of retail sales of commodities across the whole country. Together with foreign economy, non public-owned economy has accounted for more than a half of GDP. Especially with entry of China into WTO and continuously deepening of institutional reform of socialist market economy, non public-owned economic organizations have been developed fast and have become an important power that promotes local 
economic development. In the face of the new situation, party organizations at all levels have no enough awareness of building party organizations in non public-owned economic organizations and have not taken adequate work measures, so party building of the party organizations lags behind development of party building in non public-owned economic organizations. The specific details are as below:

\subsubsection{Difficulty in Organizational Construction}

In state-owned and collective enterprises, party organization and enterprise are constructed synchronously, whereas non public-owned economic organizations are run within a long period of time in an environment without any party organization. Some owners of non public-owned economic organizations have no correct knowledge in thinking, and no correct knowledge in organizing party building activities within the enterprises. In actual practice, some owners of enterprises do not support or cooperate in building of party organizations and proceeding of activities. Nevertheless, the "private" property in non public-owned economic organizations determines that the job of party building, to a certain extent, depends on recognition of owners of enterprises. Part of owners of enterprises have no unanimous knowledge in organizing party organizations, with complicated attitude of mind, and some owners even resist again party building, as a result of which party building of party organizations in these enterprises are hard to proceed successfully.

Instability of non public-owned economic organizations, to different degrees, constrains and influences party building of party organizations. Party members in non public-owned enterprises have great flowability and have no fixed quantity, so the party organizations are not adequately stable. So far as Sichuan Province is concerned, most non public-owned economic organizations are small-sized enterprises, which account for more than $90 \%$ of the total non public-owned economic organizations. The scale of the enterprises is small and its growth and extinction rate is high. According to statistics by SAIC (the State Administration of Industry and Commerce), by the end of November in 2004, the quantity of private owned enterprises in China had increased from 3.8 million to 3 million, with an increase of 0.8 million within one year. Besides, the number of party members is small, flowability of party members is great, regional distribution of party members is large and the phenomenon of "increasing in the morning and declining in the evening" is common, as a result of which some party organizations in part of enterprises can't be consolidated after the party building.

\subsubsection{Difficulty in Team Construction}

On one hand, party practitioners in non public-owned economic organizations are lacking in strength. They have neither time nor energy. $80 \%$ of party practitioners in non public-owned economic organizations are production and operation backbone in enterprises. Since they take several positions at the same time, they have neither energy nor ability to manage the work of party building. There is another part of party practitioners in non public-owned economic organizations have worry in their thought. In their eyes, the enterprise is not theirs and they have no idea about the work of party building. If they want to do a good job, they have to spend a lot of time and energy, and most importantly, financial support. They are all employees of the enterprise and they should not input too much without instructions of their boss. What is most important to serve their duties. Otherwise, they can not survive.

On the other hand, flowability of party members in non public-owned economic organizations is great and development of party members is quite difficult. Features of non public-owned economic organizations determine that flowability of party members is great. Quite a large number of party members are reluctant to "reveal" their identification of party members. To a great extent, this kind of flowability affects playing of functions of party organizations. They key to development of party building in non public-owned economic organizations is construction of the team of party building. Without participation of party members, the work of party building is water without source and a tree without root.

\subsection{There Is Still a Great Gap between Function Playing of Party Organizations and Actual Need}

\subsubsection{Deviation in Knowledge Leads to Difficulty in Function Playing of Party Organizations}

Some owners of non public-owned economic organizations believe that party organization is one that does not attend to a proper duty. And some others believe that the work of party building should be conducted in state owned enterprises, collective enterprises, public institutions, party and government offices and rural areas, while the work of party building in non public-owned economic organizations is to deliberately create problems and ask for trouble. There are still other owners of non public-owned economic organizations who even hold the view that emphasis on the work of party building in non public-owned economic organizations will affect the normal operation and development of enterprises. Therefore, they support openly but resist secretly against building party organizations and developing the work of party building in non public-owned economic 
organizations, not positive in their attitude and have a psychology of "rejecting". Some owners of non public-owned economic organizations believe that, activities of party organizations are unlikely to bring direct economic benefits to the enterprises, so they are unwilling to offer any fund. Some others even believe that developing activities of party organizations will affect production and operation of the enterprises, as a result of which the patterns of activities by party members in the enterprises are simplified and inflexible and the cohesive force and struggling force of party organizations can not be exerted sufficiently.

\subsubsection{Deficiency in Management Leads to Difficulty in Function Playing of Party Organizations}

Economic management in non public-owned economic organizations is complicated. Some organizations are directly subordinate to the party committee, some are subordinate to the party committee of the commercial bureau, and some others are subordinate to administration of town and community, which is quite unsuitable with requirement of the party organization and development of non public-owned economic organizations. With regards to the subordination and administration issue about party organizations in non public-owned economic organizations, some people believe that party organizations should be subordinate to organizations and departments above the of local county level, some believe that they should be administered by local grass-root party committee dependency and some others believe that they should be administered by local association of industry and commerce. This leads to incomplete party organizations current non public-owned economic organizations (enterprises).

\section{Basic Path of Innovation of Party Building of Non Public-owned Economic Organizations}

Innovation is the source of social development and motivation. In a new historical condition, strengthening the work of party building in non public-owned economic organizations should absolutely not remain at the existing practice and experience and has to actively comply with changes in development of the situation. Under guidance of materialistic dialectics idea, we have to start out from characteristics of private economic organizations, analyze new situations and new problems in a meticulous way, make great efforts to resolve hot issues and difficult issues, make a break-through and innovation from the multiple aspects of concept and system, gain support from employees, party members and owners of non public-owned economic organizations, develop the work of party organizations with high efficiency, open a new situation of party building in non public-owned economic organizations and offer a vigorous organizational guarantee for healthy and sustainable development of non public-owned economic organizations.

\subsection{Innovating the Concept and Expanding New Thought for the Work of Party Building}

A great social transformation always has the forerunner of a profound concept transformation and a profound concept transformation always has the duty of pushing forward a great social transformation. Innovation of the thinking is the precondition and foundation of innovation of the work of party building. Thinking determines way out and pattern determines the conclusion, thinking and way out, and thinking determines way out.

Firstly, it is to set up the superior concept. It is necessary to carefully study and comprehend the spirit of the $17^{\text {th }}$ CPC National Congress, recognize and understand the status, function and developmental trend of private economy, strengthen research on the work of party building in private economic organizations and enhance the perspectiveness.

Secondly, it is to set up the idea of being the first. According to the standard of "three favorables", it is necessary to analyze and judge out work, make positive exploration, have the courage to make practice, stay realistic and pragmatic and be the first.

Thirdly, it is to set up an overall situation. It is necessary to measure in a comprehensive way the role of party building in non public-owned economic organizations in economic development and get rid of any concept and practice that does not adapt to the requirements of "the three Represents". It is also necessary to strengthen the ideological and political job that is based on education of "thinking about source of wealth and thinking about progress when we are wealthy", positively guide and mobilize owners of non public-owned economic organizations to organize party activities in the enterprises, offer support in various aspects of human, finance, material, time and occasion, etc., put an end to the feature of family in activities of party building and make the work of party building in non public-owned enterprises form a development pattern of virtuous cycle.

\subsection{Innovating the System and Establishing a New mechanism for the Work of Party Building}

Continuous strengthening of standardization of domestic life in the CPC makes the party building realize a fundamental transfer from "building of party through movement" to "building of party with the system". Party building in non public-owned economic organizations also has to make great efforts to create a new path to resolve problems with the system and continue to reinforce the function and mechanism of institutional 
construction. Specifically speaking, it is necessary to establish and complete rules and regulations about party building in private economic organizations. Firstly, it is necessary to optimize the study system of party members. We should set up system and democratic life association system for non public-owned economic organizations to cultivate party members, encourage party members to strengthen their study and enhance the quality of party members. Secondly, it is necessary to optimize assessment system for party members. We should bring the work performance and organizational life of party members in private economic organizations into overall target management and assessment content, implement democratic assessment on party members and improve innovative force and cohesive force of party members in private economic organizations. Thirdly, it is necessary to set up the system of report on going outside by party members. We should strengthen management to party members in private economic organizations, do a good job on report and registration of party members going outside, reinforce organizational discipline of party members and make them take the path of standardization and systematism. Specifically, we need to do the following jobs:

In the first place, it is to give prominence to the key issues. We are supposed to carefully analyze the structure, operational scale and foundation of the work of party building in non public-owned economic organizations. Specially, we should emphasize the work of party building in non public-owned economic organizations that have more than three formal party members.

In the second place, it is to build the party organization in a flexible way. With regards to the features of complicated component, vast industrial scope and scattered distribution of non public-owned economic organizations, we should direct them in different categories and adopt several forms to construct party organizations in a flexible way, such as, single building, joint building, dependent building and temporary building, etc.

In the third place, it is to do a good job of supervision. It is necessary to register and tabulate non public-owned economic organizations one by one, set up detailed standing book of party building, make clear the organizational construction target and due course of limit for party organizations and practically grasp the work of supervision. The party committees at all levels and their organizational departments should adhere to periodically investigate to know about the operation condition of enterprises and the ideological condition of owners of enterprises, take an initiative in assisting non public-owned economic organizations in building party organizations, propose work countermeasures and resolve actual problems.

In the fourth place, it is to guarantee quality. It is not easy to set up party organizations, and it is more difficult to consolidate and development the party organizations. Thus, we have to correctly deal with relationship between speeding up party building and guaranteeing quality and prevent the phenomenon of "intension at first and loose at last and existing in name only" after the party organizations are built in non public-owned enterprises. As for the party organizations that have been set up, we need to adjust, in due course, the organizational institutions according to change of the number of party members.

In the fifth place, it is to rationalize the relationship. At the time when we set up party organizations, we have to define the subordination relationship and responsibility relationship in party organizations of non public-owned economic organizations according to the principles that are helpful to strengthen leadership of the party, helpful for the party organizations to launch activities and helpful to promote development of enterprises.

\subsection{Innovating Activities and Add New Vitality to the Work of Party Building}

We should develop the work of party building in a flexible way and make the working method and activity mode of the party members needed by enterprises, understood by owners of enterprises, supported by employees of the enterprises and welcomed by the party members. Firstly, we need to insist on organic combination of production and operation with the activity of party building. We need to develop activities of party organizations according to the principles of "spare-time, small-scale, flexibility and practicality", and try to realize both production and operation of enterprises and activities of party organizations. Secondly, we need to improve the activity mode of the work of party building. It is necessary to attempt to realize abundance in variety and teaching through lively activities in terms of content and form arrangement of activities by party organizations, and actively combine learning of politics, learning of business and learning of cultural and science with beneficial entertainment and sports activities. Thirdly, we need to deal with the relationship between party organization and party members in a correct way. It is necessary to respect and protect decision making, management and directing authority of owners of enterprises in the operation activities. Meanwhile, it is necessary to supervise and direct owners of enterprises to follow the law in their operation, transfer the struggling force of party organization to productivity and promote healthy development of enterprises. 


\subsection{Innovating the Carrier and Building a New Platform for the Work of Party Building}

The party members should pay attention to launching a variety of feasible and effective activities in their life and play the vanguard exemplary role. Firstly, it is to launch and create the "five good" party organization activities. We need to bring creation of "five good" party organization into the activity of creating excellence, and realize "three synchronization" of construction of the Party, construction of spiritual civilization and development of enterprises. Secondly, it is to develop "three have and three haven't" activities. That is, "We have party members at key positions, we have party members in the face of difficulties and we have party members in making a sudden and violent attack"; we haven't accidents surrounding the party members, we haven't inferior quality products around the party members and we haven't violation of rules around the party members". We should direct and educate the party members in firmly establishing the consciousness that "capacity is image", combine role playing of party members together with production and operation of enterprises, strengthen business and skill learning and attempt to make party members become the backbone of the enterprises. Thirdly, it is to launch activities that strive for vanguard positions of party members. Fourthly, it is to set up voluntary service team of party members.

\subsection{Innovating the Management and Strengthening Leadership of the Work of Party Building}

Party organizations in non public-owned economic organizations should focus on long-acting and standard management, adjust measures to conditions of enterprises, strengthen leadership, combine in an organic way result management and process management and enhance the efficiency of activities by party organizations. In the first place, we need to set up a unified and orderly stratified management system. As for private economic organizations which have more than three party members, we can set up a party branch that is subordinate to the local party committee or county private party committee. As for those private economic organizations that have only a few party members and that are not qualified to set up a party branch, we may set up a joint party branch that is subordinate to the county private party committee according to the principle of "industrial dependency and regional neighboring". In the second place, we need to strengthen community management of party members. As for those urban party members in the private economic organizations that are not qualified to set up an independent party organization, we may bring them into party organizations of the community or street. In the third place, we need to improve industrial management and dependency management. In social industry or social intermediate organizations, we need to set up party organizations and strengthen management of party members according to the mode of industrial dependency.

It is proved by the practice that, it is an effective way to strengthen leadership of the party on non public-owned economic organizations to select and send instructors of party building to non public-owned economic organizations under the new situation. This can not only resolve the problems of difficulty in building the party in non public-owned economic organizations, difficulty in launching party activities and difficulty in playing the functions of party organizations and party members, but can also change the condition of inadequate management and slack supervision on enterprises, and promote sustainable, rapid and healthy development of enterprises. The instructors of party building can both be full time and part time. These instructors can be selected among the government functionaries after negotiation of party organizations of the street, township party committee or competent department of the area where the enterprise is located with the enterprise, or can be recruited among those who are familiar with operation of the enterprise and with the work of party practice. The party organization at a higher level ought to strengthen working direction on the grass-root party branch of party organizations in non public-owned economic organizations, exchange experiences regularly, commend on any progress and guarantee that the level of the party organizations built in non public-owned economic organizations is continuously enhanced.

\section{Two Major Relationships to Be Dealt with in Innovation of party Building in Non Public-Owned Economic Organizations}

First of all, we have to correctly deal with the relationship between party building of non public-owned economic organizations and development of non public-owned economic organizations. We have to give prominence to the subject matter of development of economic organizations in order to push forward innovation of party building in non public-owned economic organizations. We need to persist in organic combination of launching activities with promoting organizational development, guide the work of party building with the goal of development, push forward the work of party building with measures of development, examine the work of party building with actual performance of development and really regard development of party organization as the starting point and final destination of the work of party building. Only in this way, can party organizations have life vitality in an economic organization entity, have cohesive force in employees and the public and have 
influences upon outside coordiniation.

Then, it is necessary to correctly deal with the relationship between party building in non public-owned economic organizations and innovation of party building. If we conduct the work of party building in non public-owned economic organizations according to the traditional thought and mode of party building, then the work of party building in non public-owned economic organizations may be lacking in vitality. In the new situation, the logic starting point of the work of party building in non public-owned economic organizations has to set up the concept of reform and innovation. It is necessary for us to actively liberate the ideological understanding from those inappropriate concepts, practices and system, boldly abandon those working methods and content that lag behind the times, explore with courage the new thought and new mechanism favorable for the work of party building, positively promote concept innovation, method innovation, institutional innovation and mechanism innovation in the work of party building and make the work of party building in non public-owned economic organizations continuously embody the feature of the times, grasp its regularity and imbued with creativity.

In a word, the work of party building in non public-owned economic organizations requires us to face up with the difficulties, change the concept of party building, continue to explore the effective approach and method of the party organizations in carrying forward the advancement, innovate the activity carrier of party members in carrying forward their advancement, launch vivid activities that embody advancement of party members and set up a long-acting mechanism that maintains advancement of party members. Only in this way, can the party organizations in non public-owned economic organizations continuously manifest the new vigor and vitality, which is helpful to vigorously promote healthy and sustainable development non public-owned economic organizations.

\section{References}

Gao, G. F. (2006). Research on the Construction of the Communist Party of China in New Economy Organization. Beijing: Party School of the Central Committee of CPC Press.

Tang et al. (2009). Play the Role of Party Organizations in the Non-public Enterprises. Dang Jian Yan Jiu, (4). 